\title{
Brazilian Protocol for Sexually Transmitted Infections 2020: viral hepatitis
}

\author{
Geraldo Duarte ${ }^{[1]}$, Paula Pezzuto ${ }^{[2]}$, Tiago Dahrug Barros ${ }^{[2],}$ \\ Gláucio Mosimann Junior ${ }^{[2]}$ and Flor Ernestina Martinez-Espinosa ${ }^{[3]}$
}

[1]. Universidade de São Paulo, Faculdade de Medicina de Ribeirão Preto, Ribeirão Preto, SP, Brasil.

[2]. Ministério da Saúde, Secretaria de Vigilância em Saúde, Brasília, DF, Brasil.

[3]. Fundação Oswaldo Cruz, Instituto Leônidas e Maria Deane, Manaus, AM, Brasil.

\begin{abstract}
This article discusses viral hepatitis, a theme addressed by the Clinical Protocol and Therapeutic Guidelines to Comprehensive Care for People with Sexually Transmitted Infections and, more precisely, by the Clinical Protocols and Therapeutic Guidelines for Hepatitis $\mathrm{B}$ and Hepatitis C and Coinfections, published by the Brazilian Ministry of Health. Besides the broad spectrum of health impairment, hepatitis A, B, and C viruses also present different transmission forms, whether parenteral, sexual, vertical, or fecal-oral. Among the strategies suggested for the control of viral hepatitis, in addition to behavioral measures, are expanded diagnosis, early vaccination against hepatitis A and hepatitis B viruses, and access to available therapeutic resources. Considering vertical transmission of the hepatitis B and hepatitis C viruses, screening for pregnant women with chronic hepatitis B and C is an essential perinatal health strategy, indicating with precision those who can benefit from the prophylactic interventions.
\end{abstract}

Keywords: Hepatitis A. Hepatitis B. Hepatitis C. Vaccines. Therapeutics. Disease prevention.

Highlighted excerpt: Viral hepatitis A, B, and C are responsible for more than 1.34 million deaths worldwide every year, from which $66 \%$ are the result of hepatitis B, $30 \%$ of hepatitis C, and $4 \%$ of hepatitis A.

\section{FOREWORD}

Viral hepatitis is a topic present in the Clinical Protocol and Therapeutic Guidelines (CPTG) for Comprehensive Care for People with Sexually Transmitted Infections (STI). It is more specifically approached in the CPTG for hepatitis B and Coinfections and the CPTG for Hepatitis C and Coinfections, both published by the Health Surveillance Department of the Brazilian Ministry of Health. The National Committee approved such documents for the Incorporation of Technologies in the Brazilian National Health System (Conitec) $)^{1-3}$. For this article's elaboration, there were a selection and analysis of available evidences from literature and discussion with specialists in STI in 2020.

\footnotetext{
Corresponding author: Geraldo Duarte.

e-mail: gduarte@fmrp.usp.br

(iD) https://orcid.org/0000-0002-1689-6142

Received 01 February 2021

Accepted 10 March 2021
}

\section{EPIDEMIOLOGICAL ASPECTS}

Viral hepatitis A, B, and C are caused by viruses presenting primary hepatic tissue tropism, posing a significant challenge to public health worldwide. Such infections are responsible for more than 1.34 million deaths worldwide every year, from which $66 \%$ are the result of hepatitis B, $30 \%$ of hepatitis C, and $4 \%$ of hepatitis $\mathrm{A}^{4}$. These deaths mainly arise from complications of hepatitis chronic forms, such as hepatic failure, cirrhosis, and hepatocellular carcinoma ${ }^{5}$. Such significant data made the World Health Organization (WHO) assume, as one of its goals, ending viral hepatitis until $2030^{6}$.

From 1999 to 2019, the Notifiable Disease Information System registered 673,389 viral hepatitis cases in Brazil. From such amount, $168,036(25 \%)$ were hepatitis A, 27,890 (36.8\%), hepatitis V, 253,307 (37.6\%), hepatitis C, and 4,156 (0.6\%), hepatitis $\mathrm{D}^{7}$.

Hepatitis A virus (HAV) belongs to the Picornaviridae family, and its genome consists of ribonucleic acid (RNA), commonly transmitted through the fecal-oral route, contaminated food, and water ingestion. Its sexual transmission has been specially reported in men who have sex with men, which reinforces the need for including prevention measures among adults ${ }^{8-12}$. 
Hepatitis B virus (HBV) belongs to the Hepadnaviridae family, whose genetic variations lead to ten different genotypes. The genotypes have relevant epidemiologic, clinical, and therapeutical aspects $^{13,14}$. Among the viruses considered hepatotropic, it is the only one with genome material composed of deoxyribonucleic acid (DNA). The most frequent HBV transmission modes are parenteral or percutaneous exposure, either vertical or sexual ${ }^{7}$. Blood is the most important transmission vehicle, but other fluids can transmit HBV as well, such as semen and vaginal content ${ }^{15}$. Predominant transmission routes vary according to HBV infection prevalence. In areas with high prevalence, perinatal and children's close contact routes are the virus's primary transmission forms ${ }^{16,17}$. In low-prevalence areas, percutaneous route and sexual contact are the contamination forms posing the greatest risk ${ }^{18}$.

Hepatitis $\mathrm{C}$ virus (HCV) belongs to the Flaviviridae family, whose genetic material is composed of a positive-sense single strand RNA, and its genetic variation allows recognizing seven different genotypes ${ }^{19}$. Its transmission takes place through percutaneous, sexual, and vertical exposure. The occurrence frequency for each of such categories varies according to the studied population and associated factors concomitance. However, it should be highlighted that the parenteral route is more efficient and prevalent in HCV transmission than sexual and vertical transmission. The highest number of new infections has been observed among injectable drug users and through syringe and needle sharing ${ }^{20,21}$.

It is known that $\mathrm{HCV}$ sexual transmission is more frequent among men who have sex with $\operatorname{men}^{22}$. As for other sexually transmitted infections, the presence of other STI, ulcerative or not, for example, human immunodeficiency virus (HIV), and unprotected sexual practices, especially those posing the greater risk of mucous bleeding (anal sex without lubricant, upper limb introduction in the vagina or anus, group sex, sexual object sharing, and sex under psychoactive drug effects), are a significant group of situations and factors facilitating $\mathrm{HCV}$ transmission ${ }^{23,24}$. Although $\mathrm{HCV}$ transmission is lower in people with heterosexual habits, and it is higher among those with a large number of sex partners or who perform anal $\operatorname{sex}^{21}$.

\section{CLINICAL ASPECTS}

Hepatitis A is self-limited, it does not evolve to a chronic disease, and its main control form is the vaccine ${ }^{25}$. Its incubation period varies from 15 to 50 days, and it is symptomatic in $70 \%$ of adults ${ }^{26,27}$. It is characterized by a sudden start of nausea, vomit, anorexia, fever, discomfort, and abdominal pain, followed by jaundice, choluria, acholia, and pruritus ${ }^{28}$. People with HAV infection transmit the virus during the incubation period, which lasts from one to six months, persisting up to one week after jaundice starting ${ }^{29}$.

HBV hepatitis can be a chronic or acute disease. In the acute form, around $70 \%$ of the cases present the subclinical form, and $30 \%$ the jaundice form, which is linked to a possibly more severe disease course ${ }^{30,31}$. In the acute phase, clinical manifestations, such as anorexia, weakness, discomfort, nausea, jaundice, choluria, and abdomen right upper quadrant pain cannot be distinguished from other viral hepatitis ${ }^{32}$.
In HBV hepatitis, the progression rate of acute to chronic infection in immunocompetent individuals is determined mainly by the age when the infection takes place, being $90 \%$ in vertical transmission ${ }^{33}, 20 \%$ to $50 \%$ from one to five years old ${ }^{34,35}$, and $0 \%$ to $10 \%$ after adolescence ${ }^{12,36}$. In its chronic form, hepatitis B is frequently asymptomatic, but it can evolve to chronic hepatic failure, cirrhosis, and hepatocellular carcinoma ${ }^{37}$.

$\mathrm{HCV}$ infection has a high chronification rate, and around 50\% to $85 \%$ of people evolve to the chronic infection form. Symptoms are present in a minority of cases (20 to $30 \%$ ), and are mainly unspecific manifestations such as tiredness, changes in sleeping, nausea, diarrhea, abdominal pain, anorexia, myalgia, arthralgia, weakness, behavior changes, and weight $\operatorname{loss}^{38,39}$. Extrahepatic manifestations include cryoglobulinemia, membranoproliferative glomerulonephritis, autoimmune thyroiditis, porphyria cutanea tarda, among others ${ }^{40}$. In case of lack of spontaneous viral elimination or treatment, an average of $20 \%$ of HCV infection cases evolve to cirrhosis over time ${ }^{41}$.

\section{DIAGNOSIS}

Hepatitis A, B, and C diagnosis is based on detecting serological (specific viral antigens and antibodies) and molecular (viral nucleic acid) markers in the infected person's blood, serum, plasma, or oral fluid, through immunoassays or molecular biology techniques ${ }^{12,42,43}$. Rapid test incorporation to the Brazilian National Health System (SUS) expended testing and early detection opportunities of such infections. They can be conducted in places without laboratory infrastructure or hard to access ${ }^{44}$.

For acute hepatitis A diagnosis, immunoassay tests detecting anti-HAV IgM antibodies in serum (up to six months after symptom starting) are used. IgG anti-HAV antibodies search, either through anti-HAV IgG or total anti-HAV (IgM and IgG), helps identify nonimmunized or previously infected individuals. Such examinations must be requested for people exposed to this infection risk situation $^{44,45}$. Anti-HAV IgG antibodies presence indicates longlasting immunity ${ }^{46}$.

Most of the people with HBV infections are asymptomatic and diagnosed in the chronic disease phase. Figure 1 shows the variation time dynamics of infection markers ${ }^{47}$. The succinct definition of such markers is given in Figure $\mathbf{2}^{48}$. For infection screening, an immunoassay laboratory test or a rapid test is used for detecting the HBV surface antigen (HBsAg). If positive, the diagnosis is supplemented by total anti-HBc, and, if possible, molecular test (HBV-DNA). HBeAg, anti-HBe, and anti-HBs, alongside the other markers, help in the clinical phase assessment and the infection evolution monitoring $16,37,42-44,49$.

In acute hepatitis $\mathrm{B}, \mathrm{HBsAg}, \mathrm{HBeAg}$, anti-HBc IgM, and HBV-DNA are the first markers to be detected. HBsAg presence confirms the infection, and it can be detected from two to 12 weeks after exposure to the virus. Its disappearance indicates that the infection has been resolved and takes place weeks after the detection, lasting for up to six months. Anti-HBc IgM disappears after the acute infection control but can be detected during flares of chronic hepatitis $\mathrm{B}^{48}$. 


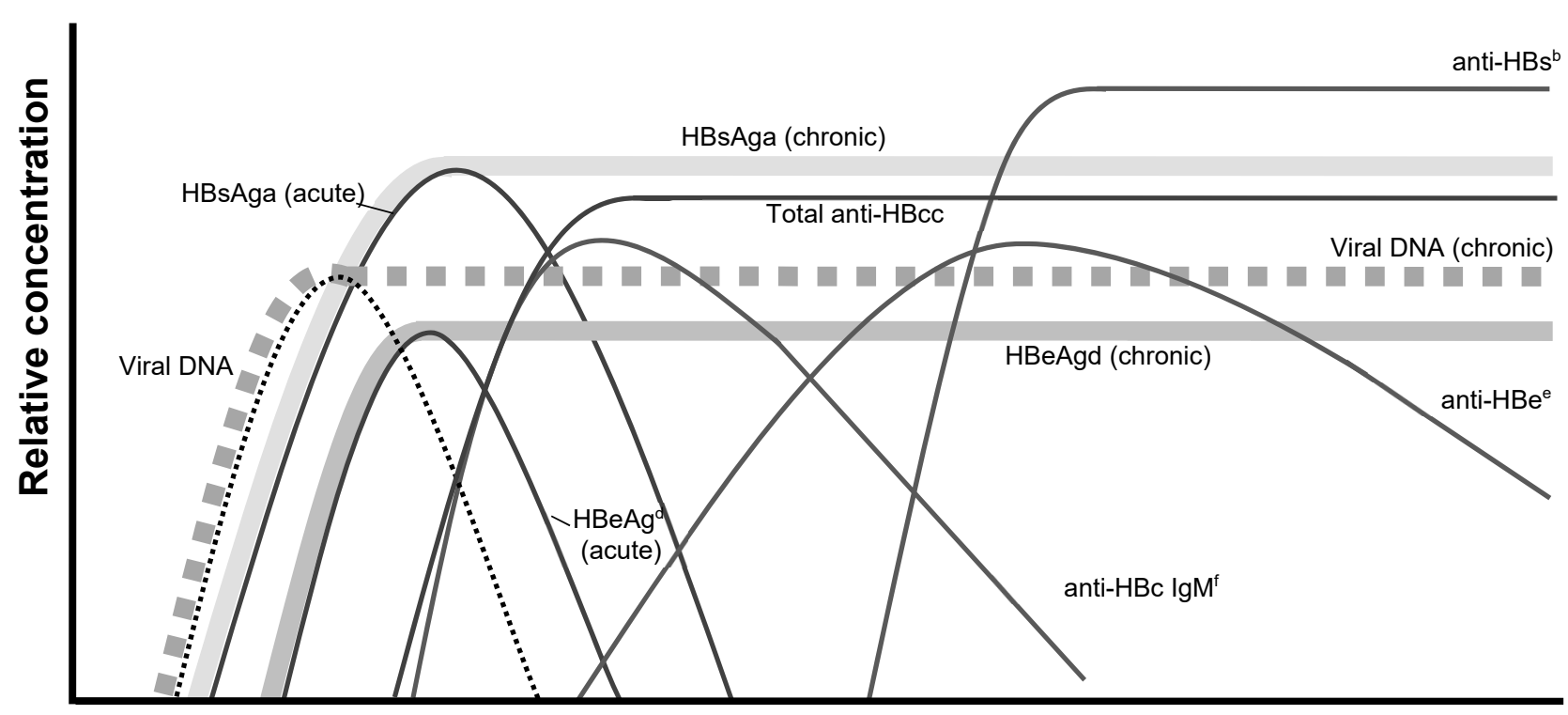

Time

Source: altered and adapted from Sablon \& Shapiro, $2005^{47}$.

Notes: a) HBsAg - hepatitis B virus surface antigen (HBV); b) Anti-HBs - antibody against HBV surface antigen; c) Total Anti-HBc - IgM and IgG class antibody against $\mathrm{HBV}$ core antigen; d) HBeAg - HBV antigen "e"; e) Anti-HBe - antibody against HBV antigen "e"; f) Anti-HBc IgM - IgM class antibody against HBV core antigen.

FIGURE 1: Hepatitis B virus infection serological markers according to the infection evolution time.

\begin{tabular}{|c|c|}
\hline Marker & Interpretation \\
\hline $\mathrm{HBsAg}^{\mathrm{a}}$ & $\begin{array}{l}\text { Marker of current hepatitis B virus infection (HBV), either acute or chronic. Detected in the acute infection initial phase. Its persistence } \\
\text { for more than six months indicates chronic infection. }\end{array}$ \\
\hline HBV-DNA ${ }^{b}$ & $\begin{array}{l}\text { Viral replication intensity marker. Present in the acute infection starting phase and can be detected before HBsAg. In chronic } \\
\text { infections, its presence is detectable in most cases. Its quantification helps classify the chronic infection clinical form. }\end{array}$ \\
\hline $\mathrm{HBeAg}^{\mathrm{C}}$ & $\begin{array}{l}\text { Viral replication marker. Its detection indicates HBV's high replication and infectivity. It is present in the acute phase and some chronic } \\
\text { forms. }\end{array}$ \\
\hline Anti-HBe ${ }^{d}$ & $\begin{array}{l}\text { Detection start coincides with the decrease of } \mathrm{HBeAg} \text { concentration. Its presence indicates viral replication reduction. Some chronic } \\
\text { disease replicative forms present this antibody in } \mathrm{HBeAg} \text { absence. }\end{array}$ \\
\hline Anti-HBc lgMe & $\begin{array}{l}\text { Recent HBV infection marker. Present during the acute infection phase. It can be detected in acute and exacerbation of chronic } \\
\text { cases. }\end{array}$ \\
\hline Anti-HBc lgG ${ }^{f}$ & $\begin{array}{l}\text { Detection starts during the acute infection phase and persists for an undetermined time. Its presence indicates current infection (when } \\
\text { HBsAg is positive) or previous contact with HBV. }\end{array}$ \\
\hline Anti-HBsAg & Indicates HBV immunity. Present after HBsAg disappearing (functional cure) or vaccine response. \\
\hline
\end{tabular}

Source: adapted from Liang, $2009^{48}$.

Notes: a) HBsAg - HBV surface antigen; b) HBV-DNA - viral nucleic acid; c) HBeAg - HBV antigen "e"; d) Anti-HBe - antibody against HBV antigen "e"; e) Anti-HBc IgM - IgM class antibody against HBV core antigen; f) Anti-HBc lgG - IgC class antibody against HBV core antigen; g) Anti-HBs - antibody against HBV surface antigen.

FIGURE 2: Hepatitis B virus infection markers interpretation.

$\mathrm{HBeAg}$ marks intense viral replication, and its detection is associated with high HBV infectiousness ${ }^{48}$. Anti-HBc IgG antibodies also have an early appearance, and they usually persist for life. They cannot classify clinical form because all infected individuals, either cured or not, present this marker. It has an epidemiological use because it indicates the previous contact with the virus or current infection. Anti-HBe presence indicates recovery starting, but many individuals presenting the disease chronic replicative form can have this marker in case of HBeAg absence ${ }^{50}$. Anti-HBs marker arises during the convalescent phase, after HBsAg disappearing. Its presence indicates immunity against HBV. In case of lack of anti-HB, the total anti-HBc is the only isolated marker of the previous infection. In individuals not exposed to HBV (negative anti-HBc $\mathrm{IgG}$ ), anti-HBs antibodies presence indicate immunity through vaccine response for hepatitis $\mathrm{B}^{51}$. 
If patients do not achieve acute infection resolution, some individuals become HBV chronic carriers. In such cases, $\mathrm{HBsAg}$ persistence for more than six months indicates chronic infection. In chronic hepatitis B, HBsAg and HBV-DNA markers stay present and detectable. The HBeAg and anti-HBe assessment, together with HBV-DNA and ALT, help monitor and assess the clinical infection phase.

Hepatitis B testing can be offered or requested for every person with high vulnerability to the disease. Those whose results are negative must be vaccinated ${ }^{16,44}$.

In HCV infection, most infected people are asymptomatic, and tracking is conducted through anti-HCV antibody detection using immunoassay tests or rapid tests. In people with reactive results, the diagnosis is supplemented by a molecular test, in this case, the reverse transcriptase-polymerase chain reaction (RT-PCR) for detecting HCV's RNA, confirming active, acute, or chronic infection. Hepatitis $\mathrm{C}$ testing must be requested for all individuals in risk situations regarding this infection ${ }^{12,52}$.

\section{TREATMENT}

A hepatitis A-specific antiviral treatment is not available. There are only medications for relieving symptoms, which generally disappear in two months ${ }^{53}$.

Only support measures are enough during HBV acute infection, considering more than $90 \%$ present spontaneous resolution. In case of need for treatment, reverse transcriptase inhibitors are used $^{54}$. In Brazil, the choice is tenofovir disoproxil fumarate or entecavir ${ }^{37}$. Preventive measures must be taken for all exposed contacts, indicating immunoglobulin and vaccination for serumnegative cases or those presenting unknown serology, according to the set criteria ${ }^{55}$.

After six months of HBsAg persistence in blood, HBV infection is considered chronic, and it must be clinically and virologically assessed for a decision on the need for drug therapy. Hepatitis B chronic form treatment aims mainly at viral suppression, thus avoiding the hepatopathy's evolution and death. HBsAg disappearance and seroconversion for antiHBs (functional cure) would be the ideal result, but it is rarely achieved. When such an objective is not attained, anti-HBe emergence, viral load reduction, and hepatic enzyme normalization are alternative outcomes ${ }^{37,56}$.

Due to its complexity, this treatment must be set under specialist guidance because it depends on multiple clinical and laboratory variables, such as the presence of significant hepatic disease, immune response to infection, viral load, and risk factors for disease progression (age and hepatocellular carcinoma family history) ${ }^{37,55}$. Liver biopsy can help assess the tissue aggression degree and cases in need of dismissing base liver disease ${ }^{57}$. The definition of HBV chronic infection antiviral therapy depends, at first, on the hepatopathy degree, on the concentration of aminotransferases, and viral load (HBV-DNA) ${ }^{58}$.

$\mathrm{HCV}$ infection can be objectively cured by using direct-action antiviral treatment. However, as it is an asymptomatic infection in most cases, a significant number of infected people are not diagnosed, many patients remain without therapy ${ }^{52}$. This treatment must be followed by a specialist, considering its complexity.

Therapeutic alternatives for HCV infection treatment incorporated into SUS show high therapeutic effectiveness, confirmed by a sustained virological response (Figure 3). When comparing similar clinical situations, all proposed schemes present analogous effectiveness. Characteristics differentiating them are recommendations for certain populations, ease posology, more affordable control, and cost. The therapy aims to sustain virological response, which means viral RNA's continuous disappearance after 12 to 24 weeks after treatment ${ }^{41}$.

\section{SURVEILLANCE, PREVENTION, AND CONTROL}

Viral hepatitis case notification is compulsory for all Brazilian states since 2016. All suspected cases must also be reported weekly to the health authority ${ }^{59}$.

According to the Special Immunobiological Reference Center's criteria, HAV infection prevention depends on the improvement of the population's sanitary conditions and vaccination (children up to five years old and people exposed to greater risk of infection $)^{56}$. However, in adults, the sexual transmission must also be taken into account, indicating and encouraging safe sex practices $^{12}$. In case of hepatitis A risk exposure, the testing is recommended, and negative people can be vaccinated up to 14 days after exposure ${ }^{29}$. 
For HBV infection control, the best strategy is vaccination, which presents high effectiveness percentages varying according to age (preterm children and people older than 60 years show lower proportions of serological conversion) and the presence of comorbidities, such as hemodialysis, hepatopathies, cancers, and people with HIV $33,56,60-62$.

Ninety percent of HBV infections acquired in the perinatal period evolving to the chronic form gives room for universal vaccination strategies of all newborns, regardless of the mother is a chronic virus carrier ${ }^{56,60}$. This strategy is crucial for achieving the goal of controlling hepatitis B up to $2030^{6,63}$.

Recommendations and care with people using illicit drugs and those performing adequate unprotected sex activity are strategies that can bring better results in HCV infection reduction ${ }^{6,21-24}$. Another way of controlling $\mathrm{HCV}$ infections is the direct-action antiviral therapy, whose success extended the discussion on treatment as a disease prevention strategy ${ }^{64}$.

\section{SPECIAL POPULATIONS AND SITUATIONS}

The approach to HAV, HBV, and HCV hepatitis during pregnancy requires attention to the prophylactic aspects encompassed both in this virus horizontal and vertical transmission. For risk exposure reduction and control, primary prophylaxis sanitary and behavioral principles are needed, together with active and passive immunoprophylaxis, when avaliable ${ }^{65,66}$. It is known that HBV and HCV vertical transmission control depends on the universal screening of such infections during prenatal care. In general, during prenatal care, it is important to identify if non-infected pregnant women's partners carry such infections, allowing them to reduce acute infections during pregnancy, for example, including the partner in prenatal care services ${ }^{67}$.

\section{Hepatitis A during pregnancy}

The short viremia period and care during delivery (avoiding the fetus' contact with the mother's stool) justify HAV vertical transmission's rare character ${ }^{68}$. Vaginal delivery is the recommendation for such women, and natural breastfeeding is authorized ${ }^{69}$.

Both immunoglobin and the HAV vaccine are safe for being used during pregnancy. In case of exposure to clinical, occupational, and lifestyle risk factors, in addition to travels to areas with high prevalence, immunoprophylaxis can be used ${ }^{12,70}$.

\section{Hepatitis B during pregnancy}

The earlier the infection takes place, the higher HBV infection chronicity rates are ${ }^{71}$. For this reason, controlling vertical transmission can reduce chronic hepatitis, cirrhosis, and hepatocellular carcinoma ${ }^{72,73}$.

$\mathrm{HBsAg}$ search is recommended as soon as possible in prenatal care, and its repetition is recommended at the moment of delivery ${ }^{74}$. For seronegative pregnant women, the three-dose vaccine scheme must start. The vaccine information does not exclude the need for checking if the pregnant women carry HBV in all such moments because vaccine serological conversion is not assured even after three doses of the vaccine ${ }^{75}$.
With normal liver function, the HBV infection prognostic is not changed by pregnancy, and the infection does not modify the pregnancy prognosis ${ }^{76,77}$. In case of compromised liver, maternal and perinatal prognostics can be negatively affected ${ }^{65}$.

HBV vertical transmission occurrence is influenced by the viral load, the carrier's $\mathrm{HBeAg}$ and anti-HBe positivity, and gestational age (infection acquired by its end increases the risk for high viral load at the moment of delivery). Without prophylactic intervention, the vertical transmission risk in chronic carriers varies from $5 \%$ to $30 \%$ ( $8 \%$ mean). However, if the pregnant woman carries HBeAg, the vertical transmission rate is high but extremely variable, taking place from $80 \%$ to $90 \%$ of cases $^{4,33,65}$.

During the prenatal care of HBV chronic carriers, all invasive conducts on the fetus and amniotic sac (amniocentesis and cordocentesis) are contraindications. When there is risk exposure, immunoprophylaxis is recommended, using, in different muscle groups, the first vaccine dose and hyperimmune hepatitis B immunoglobulin $(0.06 \mathrm{~mL} / \mathrm{kg}$ of body weight, maximum $5 \mathrm{~mL}$, intramuscular $)^{56,74,78}$.

In addition to the usual laboratory routine, the following examinations must be requested for pregnant women carrying HBV: liver function test, infection markers still not requested (HBeAg, anti-HBc, anti-HBe, anti-HBs), and viral load. All pregnant women presenting HBV viral load higher than 200,000UI/mL (corresponding to one million copies $/ \mathrm{mL}$ ) or $\mathrm{HBeAg}$ positivity must undergo vertical transmission prophylaxis. Changes in liver function indicate the need for long-term treatment and not only prophylaxis (Figure 4) ${ }^{63}$.

For HBV vertical transmission prophylaxis, using inhibitors of the nucleoside reverse transcriptase (lamivudine, tenofovir, and telbivudine) is recommended ${ }^{63,79}$. In Brazil, the option is tenofovir disoproxil fumarate (300mg, per os, single daily dose), started from the $28^{\text {th }}$ week of pregnancy, lasting to postpartum period to prevent the possible increase of viral load ${ }^{74}$. Considering the need for long-term treatment in pregnant women carrying HBV, tenofovir disoproxil fumarate is also used. Entecavir using during pregnancy is not considered safe, and it must be avoided in such a period ${ }^{80}$. Likewise, its use is not recommended while breastfeeding ${ }^{81}$.

Vaginal delivery is authorized to women carrying HBV, preventing episiotomy and deliveries using instruments (forceps or vacuum) and rapidly clamping the umbilical cord. Natural breastfeeding is also allowed ${ }^{82}$.

All newborns from women with HBV must take the vaccine first dose and HBV-specific immunoglobulin $(0.5 \mathrm{~mL}$ intramuscular), preferably in the first 12 hours of their lives, as presented in the algorithm Figure 4. After this first dose, there are many schemes for administering additional vaccine doses, some with two, others with three doses ${ }^{63}$. Countries like China, Malaysia, and Hong Kong, among others, use the schedule with two additional doses administered in the second and sixth months of life of the newborn ${ }^{83-85}$. In the United States and Canada, the schedule with two additional doses administered in the second and sixth months of life is also used. However, in preterm newborns or cases of 


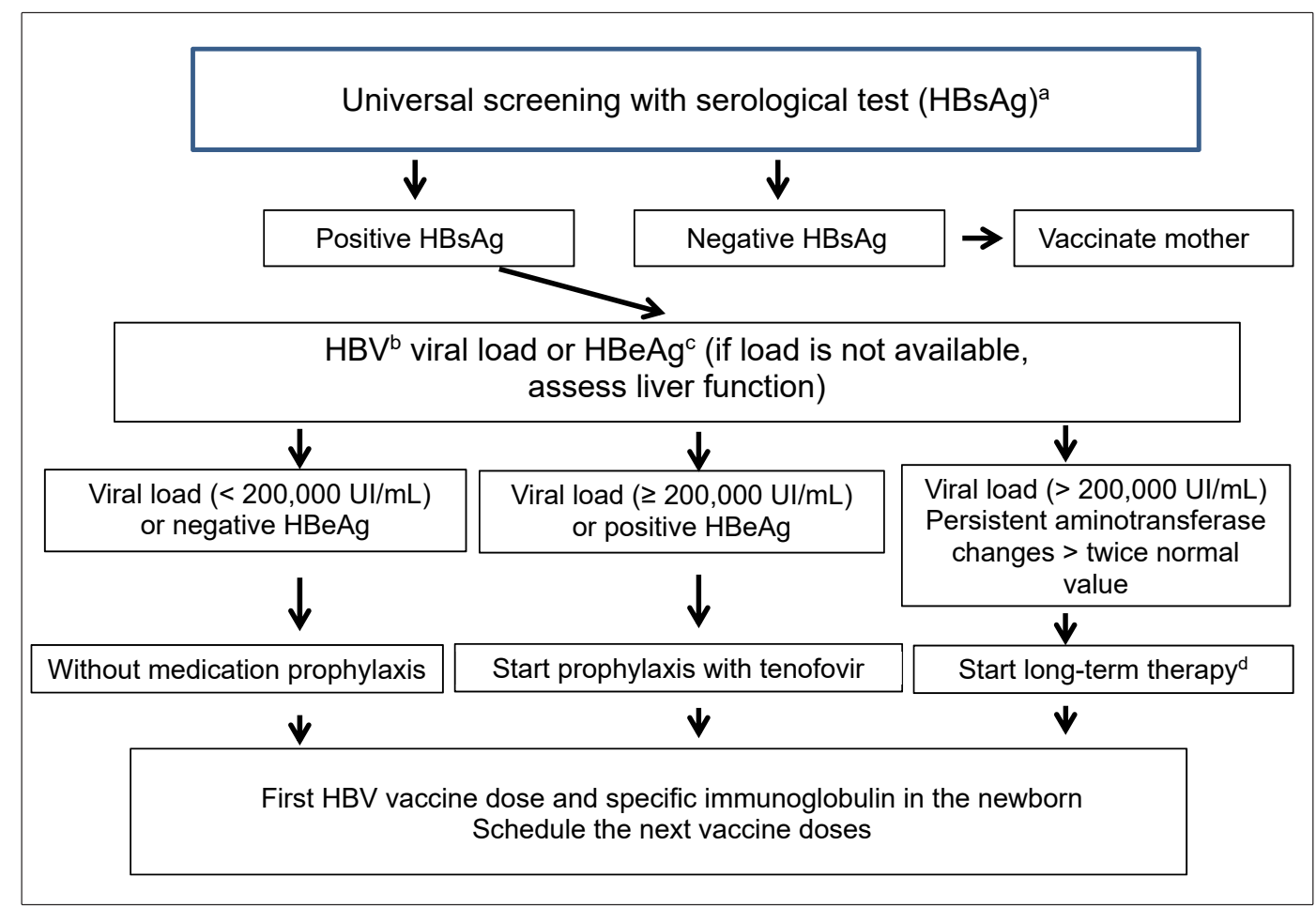

Source: altered and adapted from World Health Organization, $2020^{71}$.

Notes: a) HBsAg - HBV surface antigen; b) HBV: Hepatitis B virus; c) HBeAg - HBV antigen "e"; d) Start long-term therapy with tenofovir disoproxil fumarate because entecavir is not safe for breastfeeding women ${ }^{80,81}$.

FIGURE 4: Algorithm of preventive interventions for hepatitis B virus vertical transmission prevention.

weight lower than $2.0 \mathrm{~kg}$, the vaccine scheme considers three additional doses administered in the second, fourth, and sixth months of life ${ }^{75,86}$. In Brazil, the National Immunization Program recommends the vaccine scheme with three additional doses to the one administered at the moment of birth, using combined vaccines (pentavalent vaccine) administered in the second, fourth, and sixth months of life, regardless of newborn's prematurity or weight ${ }^{74,87}$.

Whether the vaccine scheme is used, the newborn's situation must be followed-up until infection confirmation or disregarding and assessed serum conversion ${ }^{71}$. In Brazil, such assessment is recommended from 30 and 60 days after the last dose of anti-HBV vaccine $^{74}$.

\section{Hepatitis C during pregnancy}

In 2020, the Ministry of Health added the universal screening of $\mathrm{HCV}$ infection during pregnancy ${ }^{88}$. As there is no pharmacological prophylaxis for reducing $\mathrm{HCV}$ vertical transmission, there is resistance to screening the virus during prenatal care ${ }^{4}$. However, behavioral and assistance strategies minimize such risk, such as prophylactically and therapeutically controlling other infections, forbidding invasive propaedeutics on the amniotic sac and the fetus, and preventing long-term chorioamniorrhexis. During delivery, the use of episiotomy must be avoided. The rapid clamping of the umbilical cord is recommended ${ }^{65,89,90}$. Also, it is one more opportunity for identifying $\mathrm{HCV}$ carriers who can benefit from the treatment later.
HCV vertical transmission occurs from $3.8 \%$ to $7.8 \%$ of pregnant women with chronic infection, showing a positive relationship with the viral load ${ }^{91-93}$. Such vertical transmission rates also vary depending on the gestational age when the acute infection occurs and on the presence of comorbidities, such as HIV infection ${ }^{94,95}$. There is no confirmation that HCV can cause fetal malformation ${ }^{96}$.

$\mathrm{HCV}$ infection in pregnant women is associated with adverse perinatal prognostics, such as fetal growth restriction and prematurity ${ }^{97,98}$. Such results do not seem to arise only from $\mathrm{HCV}$ effects but from the different factors coexisting in pregnant women ${ }^{94}$. Regardless of the action taken alone or in association, the need to identify pregnant women with this infection and provide appropriate prenatal care and follow-up for their children is underlined ${ }^{88,99}$. Both vaginal delivery and natural breastfeeding are authorized for women with $\mathrm{HCV}^{66,79}$ provided that there is no concomitance with HIV infection ${ }^{100}$.

\section{ACKNOWLEDGMENTS}

The authors acknowledge this work's contribution by the technical group of specialists responsible for developing the CPTG for Comprehensive Care for People with STI in 2020 and the CPTG for Hepatitis B and Coinfections and CPTG for Hepatitis C and Coinfections, published by the Ministry of Health.

\section{AUTHORS' CONTRIBUTIONS}

Duarte G, Pezzuto P, Barros TD, Mosimann Junior G, and Martinez-Espinosa FE contributed with the concept, design, 
drafting, and critical review of the manuscript. All the authors approved the final version of the work and are responsible for all its aspects, including the assurance of accuracy and integrity.

\section{ORCID}

Geraldo Duarte - 0000-0002-1689-6142

Paula Pezzuto - 0000-0001-9570-8244

Tiago Dahrug Barros - 0000-0001-6960-3801

Gláucio Mosimann Junior - 0000-0002-1687-5026

Flor Ernestina Martinez-Espinosa - 0000-0002-0325-3674

\section{REFERENCES}

1. Brasil. Ministério da Saúde. Portaria MS/SCTIE n ${ }^{\circ} 42$, de 5 de outubro de 2018. Torna pública a decisão de aprovar o Protocolo Clínico e Diretrizes Terapêuticas para Atenção Integral às Pessoas com Infecções Sexualmente Transmissíveis (IST), no âmbito do Sistema Único de Saúde - SUS [Internet]. Diário Oficial da União, Brasília (DF), 2018 out 8 [cited 2018 Oct 15];Seção 1:88. Available from: http://conitec.gov.br/ images/Relatorios/Portaria/2018/Portaria_SCTIE_N42_05_10_2018. pdf

2. Brasil. Ministério da Saúde. Portaria n ${ }^{\circ}$ 43, de 9 de dezembro de 2016. Torna pública a decisão de atualizar o Protocolo Clínico e Diretrizes Terapêuticas para Hepatite B e coinfecções, no âmbito do Sistema Único de Saúde - SUS [Internet]. Diário Oficial da União, Brasília (DF), 2016 Dec 9 [cited 2019 Dec 16];Seção 1:121. Available from: http://conitec. gov.br/images/Relatorios/Portaria/2016/Portaria SCTIE 47 2016.pdf

3. Brasil. Ministério da Saúde. Portaria MS/SCTIE $n^{\circ}$ 84, de 19 de dezembro de 2018. Torna pública a decisão de aprovar o Protocolo Clínico e Diretrizes Terapêuticas para Hepatite C e coinfecções, no âmbito do Sistema Único de Saúde - SUS [Internet]. Diário Oficial da União, Brasília (DF), 2018 Dec 20 [cited 2018 Oct 15];Seção 1:187. Available from: http://conitec.gov.br/images/Relatorios/Portaria/2018/ PortariasSCTIE 82a84 2018.pdf

4. World Health Organization - WHO. Global hepatitis report, 2017 [Internet]. Geneva: World Health Organization; 2017 [cited 2020 Oct 15]. Available from: https://www.who.int/hepatitis/publications/globalhepatitis-report2017/en/

5. Thomas DL. Global elimination of chronic hepatitis. N Engl J Med [Internet]. 2019 May [cited 2020 Oct 15];380(21):2041-50. https://doi. org/10.1056/NEJMra1810477

6. World Health Organization - WHO. Global health sector strategy on viral hepatitis 2016-2021: towards ending viral hepatitis [Internet]. Geneva: World Health Organization; 2016 [cited 2020 Oct 15 ]. Available from: https://apps.who.int/iris/bitstream/handle/10665/246177/WHO-HIV2016.06-eng.pdf;jsessionid $=65 \mathrm{FC} 34 \mathrm{~B} 07 \mathrm{~F} 74743 \mathrm{~F} 3 \mathrm{C} 634 \mathrm{~F} 238 \mathrm{D} 44 \mathrm{E} 5 \mathrm{E} 7 ?$ sequence $=1$.

7. Ministério da Saúde (BR). Secretaria de Vigilância em Saúde. Departamento de Doenças de Condições Crônicas e Infecções Sexualmente Transmissíveis. Hepatites virais | 2020. Bol Epidemiol [Internet]. $2020 \mathrm{Jul}$ [cited 2020 Oct 15]; especial. Available from: http://www.aids.gov.br/pt-br/ pub/2020/boletim-epidemiologico-hepatites-virais-2020

8. Cotter SM, Sansom S, Long T, Koch E, Kellerman S, Smith F, et al. Outbreak of hepatitis A among men who have sex with men: implications for hepatitis A vaccination strategies. J Infect Dis [Internet]. 2003 Apr [cited 2020 Oct 15];187(8):1235-40. Available from: https://doi. org/10.1086/374057
9. Beebeejaun K, Degala S, Balogun K, Simms I, Woodhall SC, Heinsbroek E, et al. Outbreak of hepatitis A associated with men who have sex with men (MSM), England, July 2016 to January 2017. Euro Surveill [Internet]. $2017 \mathrm{Feb}$ [cited 2020 Oct 15];22(5):30454. Available from: https://doi.org/10.2807/1560-7917.ES.2017.22.5.30454

10. Freidl GS, Sonder GJ, Bovée LP, Friesema IH, van Rijckevorsel GG, Ruijs WL, et al. Hepatitis A outbreak among men who have sex with men (MSM) predominantly linked with the EuroPride, the Netherlands, July 2016 to February 2017. Euro Surveill [Internet]. 2017 [cited 2020 Oct 15];22(8):30468. Available from: https://doi.org.10.2807/1560-7917. ES.2017.22.8.30468

11. Chen GJ, Lin KY, Sun HY, Sheng WH, Hsieh SM, Huang YC, et al. Incidence of acute hepatitis A among HIV-positive patients during an outbreak among MSM in Taiwan: Impact of HAV vaccination. Liver Int [Internet]. 2018 Apr [cited 2020 Oct 15];38(4):594-601. Available from: https://doi.org/10.1111/liv.13468

12. Ministério da Saúde (BR). Secretaria de Vigilância em Saúde Departamento de Doenças de Condições Crônicas e Infecções Sexualmente Transmissíveis. Protocolo clínico e diretrizes terapêuticas para atenção integral às pessoas com infecções sexualmente transmissíveis [Internet]. Brasília: Ministério da Saúde; 2020 [cited 2020 Oct 15]. Available from: http://www.aids.gov.br/pt-br/pub/2015/ protocolo-clinico-e-diretrizes-terapeuticas-para-atencao-integralpessoas-com-infeccoes

13. Kramvis, A. Genotypes and genetic variability of hepatitis B virus. Intervirology [Internet]. 2014 [cited 2020 Oct 15];57:141-50. Available from: https://doi.org/10.1159/000360947

14. Aguilera A, Trastoy R, Rodríguez-Frias F, Muñoz-Bellido JL, Melón S, Suárez A, Orduña A, et al. GEHEP 010 study: prevalence and distribution of hepatitis B virus genotypes in Spain (2000-2016). J Infect [Internet]. 2020 [cited 2020 Oct 15];81(4):600-6. Available from: https://doi.org/10.1016/j.jinf.2020.07.019

15. Inoue $T$, Tanaka Y. Hepatitis $B$ virus and its sexually transmitted infection - an update. Microb Cell [Internet]. 2016 Sep [cited 2020 Oct 15];3(9):420-37. Available from: https://doi.org/10.15698/mic2016.09.527

16. World Health Organization - WHO. Guidelines for the prevention, care and treatment of persons with chronic hepatitis B infection [Internet] Geneva: World Health Organization; 2015 [cited 2020 Oct 15]. Available from: https://www.who.int/hiv/pub/hepatitis/hepatitis-b-guidelines/en/

17. Souto FJD. Distribution of hepatitis B infection in Brazil: the epidemiological situation at the beginning of the 21st century. Rev Soc Bras Med Trop [Internet]. 2016 [cited 2020 Oct 15];49(1):11-23. Available from: https://doi.org/10.1590/0037-8682-0176-2015

18. Nguyen MH, Wong G, Gane E, Kao JH, Dusheiko G. Hepatitis B virus: advances in prevention, diagnosis, and therapy. Clin Microbiol Rev [Internet]. 2020 Feb [cited 2020 Oct 15];33(2):e00046-19. Available from: https://doi.org/10.1128/CMR.00046-19

19. Smith DB, Bukh J, Kuiken C, Muerhoff AS, Rice CM, Stapleton JT, et al. Expanded classification of hepatitis $\mathrm{C}$ virus into 7 genotypes and 67 subtypes: Updated criteria and genotype assignment web resource. Hepatology [Internet]. 2014 Jan [cited 2020 Oct 15];59(1):318-27. Available from: https://doi.org/10.1002/hep.26744

20. World Health Organization - WHO. Guidelines for the screening, care and treatment of persons with chronic hepatitis $\mathrm{C}$ infection [Internet]. Geneva: World Health Organization; 2016 [cited 2020 Oct 15]. Available from: https://apps.who.int/iris/bitstream/ handle/10665/205035/9789241549615 eng.pdf;jsessionid=AFFE108E3 96C753F82C287424A20DAEA? sequence $=1$

21. Schillie S, Wester C, Osborne M, Wesolowski L, Ryerson AB. CDC Recommendations for hepatitis c screening among adults - United 
States, 2020. MMWR Recomm Rep [Internet]. 2020 Apr [cited 2020 Oct 15];69(2):1-17. Available from: https://doi.org/10.15585/mmwr.rr6902a1

22. Hagan H, Jordan AE, Neurer J, Cleland CM. Incidence of sexually transmitted hepatitis $\mathrm{C}$ virus infection in HIV-positive men who have sex with men. AIDS [Internet]. 2015 Nov [cited 2020 Oct 15];29(17):233545. Available from: https://doi.org.10.1097/QAD.0000000000000834

23. Delaunay CL, Cox J, Klein M, Lambert G, Grace D, Lachowsky NJ, Maheu-Giroux M. Trends in hepatitis $\mathrm{C}$ virus seroprevalence and associated risk factors among men who have sex with men in Montréal: results from three cross-sectional studies $(2005,2009,2018)$. Sex Transm Infect [Internet]. $2020 \mathrm{Jul}$ [cited 2020 Oct 15]. Available from: https://doi/org/10.1136/sextrans-2020-054464

24. Li H, Marks KM, Talal AH, van Seggelen WO, Akil B, Radix A, et al. Assessing routes of hepatitis $\mathrm{C}$ transmission in HIV-infected men who have sex with men using single genome sequencing. PLoS One [Internet]. $2020 \mathrm{Jul}$ [cited 2020 Oct 15];15(7):e0235237. Available from: https://doi.org/10.1371/journal.pone.0235237

25. Linder KA, Malani PN. Hepatitis A. JAMA [Internet]. 2017 Dec [cited 2020 Oct 15];318(23):2393. Available from: https://doi.org/10.1001/ jama.2017.17244

26. Kemmer NM, Miskovsky EP. Hepatitis A. Infect Dis Clin North Am [Internet]. 2000 Aug [cited 2020 Oct 15];14(3):605-15. Available from: https://doi.org10.1016/s0891-5520(05)70123-9

27. Lemon SM. Type A viral hepatitis. New developments in an old disease. N Engl J Med [Internet]. 1985 Oct [cited 2020 Oct 15];313(17):1059-67. Available from: https://doi.org/10.1056/NEJM198510243131706

28. Centers for Disease Control and Prevention - CDC. Viral hepatitis surveillance: United States, 2013 [Internet]. Atlanta: US Department of Health and Human Services; 2016 [cited 2020 Oct 15]. Available from: https://www.cdc.gov/hepatitis/statistics/2013surveillance/index.htm.

29. Workowski KA, Bolan GA, Centers for Disease Control and Prevention CDC. Sexually transmitted diseases treatment guidelines, 2015. MMWR Recomm Rep [Internet]. 2015 [cited 2020 Oct 15];64:1. Available from: https://www.cdc.gov/mmwr/preview/mmwrhtml/rr6403a1.htm.

30. Rehermann B, Ferrari C, Pasquinelli C, Chisari FV. The hepatitis B virus persists for decades after patients' recovery from acute viral hepatitis despite active maintenance of a cytotoxic T-lymphocyte response. Nat Med [Internet]. 1996 Oct [cited 2020 Oct 15];2(10):1104-8. Available from: https://doi.org/10.1038/nm1096-1104

31. Liaw YF, Tsai SL, Sheen IS, Chao M, Yeh CT, Hsieh SY. Clinical and virological course of chronic hepatitis B virus infection with hepatitis $\mathrm{C}$ and D virus markers. Am J Gastroenterol [Internet]. 1998 Mar [cited 2020 Oct 15];93(3):354-9. Available from: https://doi.org/10.1111/j.1572$\underline{0241.1998 .00354 . x}$

32. Westbrook RH, Dusheiko G. Natural history of hepatitis C. J Hepatol [Internet]. 2014 Nov [cited 2020 Oct 15];61(Suppl 1):S58-68. Available from: https://doi.org/10.1016/j.jhep.2014.07.012

33. Stevens CE, Toy P, Kamili S, Taylor PE, Tong MJ, Xia GL, et al. Eradicating hepatitis B virus: the critical role of preventing perinatal transmission. Biologicals [Internet]. 2017 Nov [cited 2020 Oct 15];50:319. Available from: https://doi.org/10.1016/j.biologicals.2017.08.008

34. Beasley RP, Hwang LY, Lin CC, Leu ML, Stevens CE, Szmuness W, et al. Incidence of hepatitis B virus infections in preschool children in Taiwan. J Infect Dis [Internet]. 1982 Aug [cited 2020 Oct 15];146(2):198204. Available from: https://doi.org/10.1093/infdis/146.2.198

35. Coursaget P, Yvonnet B, Chotard J, Vincelot P, Sarr M, Diouf C, et al. Age-and sex-related study of hepatitis B virus chronic carrier state in infants from an endemic area (Senegal). J Med Virol [Internet]. 1987 May [cited 2020 Oct 15];22(1):1-5. Available from: https://doi. org/10.1002/jmv.1890220102
36. Alter MJ. Epidemiology of hepatitis C virus infection. World J Gastroenterol [Internet]. 2007 May [cited 2020 Oct 15];13(17):2436-41. Available from: https://doi.org/10.3748/wjg.v13.i17.2436

37. Ministério da Saúde (BR). Secretaria de Vigilância em Saúde. Departamento de Vigilância, Prevenção e Controle das Infecções Sexualmente Transmissíveis, do HIV/ Aids e das Hepatites Virais. Protocolo clínico e diretrizes terapêuticas para hepatite b e coinfecções [Internet]. Brasília: Ministério da Saúde; 2017 [cited 2020 Oct 15]. Available from: http://www.aids.gov.br/pt-br/pub/2016/protocolo-clinicoe-diretrizes-terapeuticas-para-hepatite-b-e-coinfeccoes

38. Forton DM, Thomas HC, Murphy CA, Allsop JN, Foster GR, Main $\mathrm{J}$, et al. Hepatitis $\mathrm{C}$ and cognitive impairment in a cohort of patients with mild liver disease. Hepatology [Internet]. 2002 [cited 2020 Oct 15];35:433. Available from: https://doi.org/10.1053/jhep.2002.30688

39. Evon DM, Stewart PW, Amador J, Serper M, Lok AS, Sterling RK, et al. A comprehensive assessment of patient reported symptom burden, medical comorbidities, and functional well being in patients initiating direct acting antiviral therapy for chronic hepatitis C: results from a large US multi-center observational study. PLoS One [Internet]. 2018 Aug [cited 2020 Oct 15];13(8):e0196908. Available from: https://doi. org/10.1371/journal.pone.0196908

40. Gill K, Ghazinian H, Manch R, Gish R. Hepatitis C virus as a systemic disease: reaching beyond the liver. Hepatol Int [Internet]. 2016 [cited 2020 Oct 15];10(3):415-23. Available from: https://doi.org10.1007/ s12072-015-9684-3

41. Ministério da Saúde (BR). Secretaria de Vigilância em Saúde Departamento de Vigilância, Prevenção e Controle das Infecções Sexualmente Transmissíveis, do HIV/Aids e das Hepatites Virais. Protocolo clínico e diretrizes terapêuticas para hepatite c e coinfecções [Internet]. Brasília: Ministério da Saúde; 2019 [cited 2020 Oct 15]. Available from: http://www.aids.gov.br/pt-br/pub/2017/protocolo-clinicoe-diretrizes-terapeuticas-para-hepatite-c-e-coinfeccoes

42. Peeling RW, Boeras DI, Marinucci F, Easterbrook P. The future of viral hepatitis testing: innovations in testing technologies and approaches. BMC Infect Dis [Internet]. 2017 Nov [cited 2020 Oct 15];17(Suppl 1):699. Available from: https://doi.org/10.1186/s12879-017-2775-0

43. Easterbrook PJ, Roberts T, Sands A, Peeling R. Diagnosis of viral hepatitis. Curr Opin HIV AIDS [Internet]. 2017 May [cited 2020 Oct 15];12(3):302-314. Available from: https://doi.org/10.1097/ COH.0000000000000370

44. Ministério da Saúde (BR). Secretaria de Vigilância em Saúde. Departamento de Vigilância, Prevenção e Controle das Infecções Sexualmente Transmissíveis, do HIV/ Aids e das Hepatites Virais. Manual técnico para o diagnóstico das hepatites virais [Internet]. 2. ed. Brasília: Ministério da Saúde; 2018 [cited 2020 Oct 15]. Available from: http:// www.aids.gov.br/pt-br/pub/2015/manual-tecnico-para-o-diagnosticodas-hepatites-virais

45. Ntouva A, Sibal B, Balogun K, Mandal S, Harding N. Hepatitis A in primary care: working in partnership for diagnosis, management, and prevention of outbreaks. Br J Gen Pract [Internet]. 2019 Sep [cited 2020 Oct 15];69(687):521-2. Available from: https://doi.org/10.3399/bjgp19X705965

46. Yin S, Barker L, Ly KN, Kilmer G, Foster MA, Drobeniuc J, Jiles RB. Susceptibility to hepatitis A virus infection in the United States, $2007-$ 2016. Clin Infect Dis [Internet]. 2020 Mar [cited 2020 Oct 15]:ciaa298. Available from: https://doi.org/10.1093/cid/ciaa298

47. Sablon E, Shapiro F. Advances in molecular diagnosis of HBV infection and drug resistance. Int J Med Sci [Internet]. 2005 [cited 2020 Oct 15];2(1):8-16. Available from: https://doi.org.10.7150/ijms.2.8

48. Liang TJ. Hepatitis B: the virus and disease. Hepatology [Internet]. 2009 May [cited 2020 Oct 15];49(5 Suppl):S13-21. Available from: https://doi. org/10.1002/hep.22881 
49. Lau KCK, Joshi SS, Mahoney DJ, Mason AL, van Marle G, Osiowy $\mathrm{C}$, et al. Differences in HBV replication, APOBEC3 family expression, and inflammatory cytokine levels between wild-type HBV and precore (G1896A) or basal core promoter (A1762T/G1764A) mutants. Front Microbiol [Internet]. 2020 Jul [cited 2020 Oct 15];11:1653. Available from: https://doi.org/10.3389/fmicb.2020.01653

50. World Health Organization - WHO. Guidelines on hepatitis B and C testing [Internet]. Geneva: World Health Organization; 2017 [cited 2020 Oct 15]. Available from: https://www.who.int/hepatitis/publications/ guidelines-hepatitis-c-b-testing/en/

51. Trépo C, Chan HLY, Lok A. Hepatitis B virus infection. Lancet [Internet]. 2014 Dec [cited 2020 Oct 15];384(9959):2053-63. Available from: https://doi.org/10.1016/S0140-6736(14)60220-8

52. World Health Organization - WHO. Guidelines for the care and treatment of persons diagnosed with chronic hepatitis $\mathrm{C}$ virus infection. Geneva: World Health Organization; 2018 [cited 2020 Oct 15]. Available from: https://www.who.int/hepatitis/publications/hepatitis-c-guidelines-2018/ en/

53. Shin EC, Jeong SH. Natural history, clinical manifestations, and pathogenesis of hepatitis A. Cold Spring Harb Perspect Med [Internet]. 2018 Sep [cited 2020 Oct 25];8(9):a031708. Available from: https://doi. org/10.1101/cshperspect.a031708

54. Terrault NA, Lok ASF, McMahon BJ, Chang KM, Hwang JP, Jonas $\mathrm{MM}$, et al. Update on prevention, diagnosis, and treatment of chronic hepatitis B: AASLD 2018 hepatitis B guidance. Clin Liver Dis [Internet]. 2018 Aug [cited 2020 Oct 15];12(1):33-4. Available from: https://doi. org/10.1002/cld.728

55. Ministério da Saúde (BR). Secretaria de Vigilância em Saúde. Departamento de Imunização e Doenças Transmissíveis. Manual dos centros de referência para imunobiológicos especiais [Internet]. Brasília: Ministério da Saúde; 2019 [cited 2020 Oct 15]. Available from: https://portalarquivos2.saude.gov.br/images/pdf/2019/dezembro/11/ manual-centros-referencia-imunobiologicos-especiais-5ed.pdf

56. Lok AS, Zoulim F, Dusheiko G, Ghany MG. Hepatitis B cure: from discovery to regulatory approval. J Hepatol [Internet]. 2017 [cited 2020 Oct 15];67(4):847-61. Available from: https://doi.org/10.1016/j. ihep.2017.05.008

57. Kumar M, Sarin SK, Hissar S, Pande C, Sakhuja P, Sharma BC, et al. Virologic and histologic features of chronic hepatitis B virus-infected asymptomatic patients with persistently normal ALT. Gastroenterology [Internet]. 2008 May [cited 2020 Oct 15];134(5):1376-84. Available from: https://doi.org/10.1053/j.gastro.2008.02.075

58. Sinn DH, Lee J, Goo J, Kim K, Gwak GY, Paik YH, et al. Hepatocellular carcinoma risk in chronic hepatitis B virus-infected compensated cirrhosis patients with low viral load. Hepatology [Internet]. 2015 Sep [cited 2020 Oct 15];62(3):694-701. Available from: https://doi. org/10.1002/hep. 27889

59. Brasil. Ministério da Saúde. Portaria MS/GM n ${ }^{\circ}$ 204, de 17 de fevereiro de 2016. Define a Lista Nacional de Notificação Compulsória de doenças, agravos e eventos de saúde pública nos serviços de saúde públicos e privados em todo o território nacional, nos termos do anexo, e dá outras providências [Internet]. Diário Oficial da União, Brasília (DF), 2016 Feb 18 [cited 2020 Oct 15];Seção 1:23. Available from: https://bvsms.saude. gov.br/bvs/saudelegis/gm/2016/prt0204 1702 2016.html

60. Schillie SF, Murphy TV. Seroprotection after recombinant hepatitis B vaccination among newborn infants: a review. Vaccine [Internet]. 2013 May [cited 2020 Oct 15];31(21):2506-16. Available from: https://doi. org/10.1016/j.vaccine.2012.12.012

61. Schönberger K, Riedel C, Rückinger S, Mansmann U, Jilg W, Kries $\mathrm{RV}$. Determinants of long-term protection after hepatitis B vaccination in infancy: a meta-analysis. Pediatr Infect Dis J [Internet]. 2013 [cited 2020 Oct 15];32(4):307-13. Available from: https://doi.org/10.1097/ INF.0b013e31827bd1b0

62. Yeo YH, Le MH, Chang ET, Henry L, Nguyen MH. Prevalence of undetectable vaccine-induced immunity against hepatitis B virus in US adults at high risk for infection. Hepatology [Internet]. 2019 Apr [cited 2020 Oct 15];69(4):1385-97. Available from: https://doi.org/10.1002/ hep.30285

63. World Health Organization - WHO. Prevention of mother-to-child transmission of hepatitis B virus: guidelines on antiviral prophylaxis in pregnancy [Internet]. Geneva: World Health Organization; 2020 [cited 2020 Oct 15]. Available from: https://apps.who.int/iris/bitstream/hand le $/ 10665 / 333391 / 9789240002708$-eng.pdf?sequence $=1 \&$ isAllowed $=y$

64. Hajarizadeh B, Grebely J, Martinello M, Matthews GV, Lloyd AR, Dore GJ. Hepatitis C treatment as prevention: evidence, feasibility, and challenges. Lancet Gastr Hepatol [Internet]. 2016 [cited 2020 Oct 15];1(4):317-27. Available from: https://doi.org/10.1016/S24681253(16)30075-9

65. Duarte G, Coutinho CM, Metzker RC. Hepatites B e C em gestantes. In: Madi JM, Araujo BF, Zatti H. Doenças infecciosas na prática obstétrica e neonatal. Rio de Janeiro: Editora Rubio; 2008. p. 49-57.

66. Seto MT, Cheung KW, Hung IFN. Management of viral hepatitis A, C, $\mathrm{D}$ and $\mathrm{E}$ in pregnancy. Best Pract Res Clin Obstet Gynaecol [Internet]. 2020 [cited 2020 Oct 15];S1521-6934(20)30050-X. Available from: https://doi.org/10.1016/j.bpobgyn.2020.03.009

67. Duarte G. Extensão da assistência pré-natal ao parceiro como estratégia de aumento da adesão ao pré-natal e redução da transmissão vertical de infecções. Rev Bras Ginecol Obstet [Internet]. 2007 Apr [cited 2020 Oct 15];29(4):171-4. Available from: http://dx.doi.org/10.1590/S010072032007000400001

68. Ranger-Rogez S, Alain S, Denis F. Virus des hépatites: transmission mère-enfant [Hepatitis viruses: mother to child transmission]. Pathol Biol (Paris) [Internet]. 2002 Nov [cited 2020 Oct 15];50(9):568-75. Available from: https://doi.org/10.1016/s0369-8114(02)00351-6

69. Rac MW, Sheffield JS. Prevention and management of viral hepatitis in pregnancy. Obstet Gynecol Clin North Am [Internet]. 2014 [cited 2020 Oct 15];41(4):573-92. Available from: https://doi.org/10.1016/j. ogc.2014.08.004

70. Nelson NP, Weng MK, Hofmeister MG, Moore KL, Doshani M, Kamili S, et al. Prevention of hepatitis A virus infection in the united states: recommendations of the advisory committee on immunization practices, 2020. MMWR Recomm Rep [Internet]. 2020 Jul [cited 2020 Oct 15];69(5):1-38. Available from: https://doi.org/10.15585/mmwr. $\underline{\operatorname{rr} 6905 \mathrm{a} 1}$

71. Cheung KW, Lao TT. Hepatitis B - vertical transmission and the prevention of mother-to-child transmission. Best Pract Res Clin Obstet Gynaecol [Internet]. 2020 Mar [cited 2020 Oct 15];68:78-88. Available from: https://doi.org/10.1016/j.bpobgyn.2020.02.014

72. Indolfi G, Easterbrook P, Dusheiko G, Siberry G, Chang MH, Thorne $\mathrm{C}$, et al. Hepatitis B virus infection in children and adolescents. Lancet Gastroenterol Hepatol [Internet]. 2019 Jun [cited 2020 Oct 15];4(6):46676. Available from: https://doi.org/10.1016/S2468-1253(19)30042-1

73. United States Preventive Services Task Force, Owens DK, Davidson KW, Krist AH, Barry MJ, Cabana M, et al. Screening for hepatitis B virus infection in pregnant women: US preventive services task force reaffirmation recommendation statement. JAMA [Internet]. 2019 Jul [cited 2020 Oct 15];322(4):349-54. Available from: https://doi. org/10.1001/jama.2019.9365

74. Ministério da Saúde (BR). Secretaria de Vigilância em Saúde. Departamento de Vigilância, Prevenção e Controle das Infecções 
Sexualmente Transmissíveis, do HIV/ Aids e das Hepatites Virais. Protocolo clínico e diretrizes terapêuticas para prevenção da transmissão vertical de HIV, sífilis e hepatites virais [Internet]. Brasília: Ministério da Saúde; 2019 [cited 2020 Oct 15]. Available from: http://www.aids. gov.br/pt-br/pub/2015/protocolo-clinico-e-diretrizes-terapeuticas-paraprevencao-da-transmissao-vertical-de-hiv

75. Schillie S, Vellozzi C, Reingold A, Harris A, Haber P, Ward JW, et al. Prevention of hepatitis B virus infection in the United States: recommendations of the Advisory Committee on Immunization Practices. MMWR Recomm Rep [Internet]. 2018 Jan [cited 2020 Oct 15];67(1):1-31. Available from: https://doi.org/10.15585/mmwr.rr6701a1

76. Lobstein S, Faber R, Tillmann HL. Prevalence of hepatitis B among pregnant women and its impact on pregnancy and newborn complications at a tertiary hospital in the eastern part of Germany. Digestion [Internet]. 2011 [cited 2020 Oct 15];83(1-2):76-82. Available from: https://doi.org/10.1159/000320455

77. Pan CQ, Duan ZP, Bhamidimarri KR, Zou HB, Liang XF, Li J, et al. An algorithm for risk assessment and intervention of mother to child transmission of hepatitis B virus. Clin Gastroenterol Hepatol [Internet]. 2012 May [cited 2020 Oct 15];10(5):452-9. Available from: https://doi. org/10.1016/i.cgh.2011.10.041

78. Kwon SY, Lee CH. Epidemiology and prevention of hepatitis B virus infection. Korean J Hepatol [Internet]. 2011 Jun [cited 2020 Oct 15];17(2):87-95. Available from: https://doi.org/10.3350/ kjhep.2011.17.2.87

79. Pan CQ, Duan Z, Dai E, Zhang S, Han G, Wang Y, et al. China study group for the mother-to-child transmission of hepatitis B. Tenofovir to prevent hepatitis B transmission in mothers with high viral load. N Engl J Med [Internet]. 2016 Jun [cited 2020 Oct 15];374(24):2324-34. Available from: https://doi.org/10.1056/NEJMoa1508660

80. Ayoub WS, Cohen E. Hepatitis B management in the pregnant patient: an update. J Clin Transl Hepatol [Internet]. 2016 Sep [cited 2020 Oct 15];4(3):241-7. Available from: https://doi.org/10.14218/ JCTH.2016.00014

81. National Institutes of Health (USA). Drugs and lactation database (LactMed) [Internet]. Bethesda (MD): National Library of Medicine; 2020 [cited 2020 Oct 15]. Available from: https://www.ncbi.nlm.nih. gov/books/NBK501744/

82. Society for Maternal-Fetal Medicine - SMFM, Dionne-Odom J, Tita AT, Silverman NS. \#38: Hepatitis B in pregnancy screening, treatment, and prevention of vertical transmission. Am J Obstet Gynecol [Internet]. 2016 Jan [cited 2020 Oct 15];214(1):6-14. Available from: https://doi. org/10.1016/j.ajog.2015.09.100

83. Woodring J, Pastore R, Brink A, Ishikawa N, Takashima Y, Tohme RA. Progress toward hepatitis B control and elimination of mother-to-child transmission of hepatitis B virus - Western Pacific Region, 2005-2017. MMWR Morb Mortal Wkly Rep [Internet]. 2019 Mar [cited 2020 Oct 15];68(8):195-200. Available from: https://doi.org/10.15585/mmwr. mm6808a2

84. Zheng H, Zhang GM, Chan PL, Wang FZ, Rodewald LE, Miao N, et al. Compliance among infants exposed to hepatitis B virus in a postvaccination serological testing program in four provinces in China. Infect Dis Poverty [Internet]. 2019 Jul [cited 202 Oct 15];8(1):57. Available from: https://doi.org/10.1186/s40249-019-0568-y

85. Huang $\mathrm{H}, \mathrm{Xu} \mathrm{C}$, Liu L, Chen L, Zhu X, Chen J, et al. Increased protection of earlier use of immunoprophylaxis in preventing perinatal transmission of hepatitis B virus. Clin Infect Dis [Internet]. $2020 \mathrm{Jul}$ [cited 2020 Oct 15];ciaa898. Available from: https://doi.org/10.1093/cid/ ciaa898

86. Castillo E, Murphy K, van Schalkwyk J. No. 342-hepatitis B and pregnancy. J Obstet Gynaecol Can [Internet]. 2017 [cited 202
Oct 15];39(3):181-90. Available from: https://doi.org/10.1016/j. jogc.2016.11.001

87. Ministério da Saúde (BR). Programa Nacional de Imunização. Anexo V: instrução normativa referente ao calendário nacional de vacinação 2020 [Internet]. Brasília: Ministério da Saúde; 2019 [cited 2020 Oct 15]. Available from: https://www.saude.gov.br/images/pdf/2020/marco/04/ Instru----o-Normativa-Calend--rio-Vacinal-2020.pdf

88. Brasil. Ministério da Saúde. Secretaria de Ciência, Tecnologia, Inovação e Insumos Estratégicos em Saúde. Departamento de Gestão e Incorporação de Tecnologias e Inovação em Saúde. Portaria MS/SCTIE $\mathrm{N}^{\circ} 32$, de 11 de agosto de 2020. Torna pública a decisão de incorporar a testagem universal para hepatite viral $\mathrm{C}$ em gestantes no pré-natal, conforme protocolo do Ministério da Saúde, no âmbito do Sistema Único de Saúde - SUS [Internet]. Diário Oficial da União, Brasília (DF), 2020 Aug 19 [cited 2020 Oct 15];Seção 1:18. Available from: http://conitec.gov.br/images/Relatorios/Portaria/2018/Portaria_SCTIE_

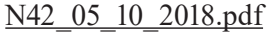

89. Jhaveri R, Broder T, Bhattacharya D, Peters MG, Kim AY, Jonas MM. Universal screening of pregnant women for hepatitis C: the time is now. Clin Infect Dis [Internet]. 2018 [cited 2020 Oct 15];67(10):1493-7. Available from: https://doi.org/10.1093/cid/ciy586

90. Rossi RM, Wolfe C, Brokamp R, McAllister JM, Wexelblatt S, Warshak CR, Hall ES. Reported prevalence of maternal hepatitis C virus infection in the United States. Obstet Gynecol [Internet]. 2020 Feb [cited 2020 Oct 15];135(2):387-95. Available from: https://doi.org/10.1097/ AOG.0000000000003644

91. Conte D, Fraquelli M, Prati D, Colucci A, Minola E. Prevalence and clinical course of chronic hepatitis $\mathrm{C}$ virus (HCV) infection and rate of HCV vertical transmission in a cohort of 15,250 pregnant women. Hepatology [Internet]. 2000 Mar [cited 2020 Oct 15];31(3):751-5. Available from: https://doi.org/10.1002/hep.510310328

92. Syriopoulou, V, Nikolopoulou G, Daikos GL, Theodoridou M, Pavlopoulou I, Nicolaidou P, et al. Mother to child transmission of hepatitis C virus: rate of infection and risk factors. Scand J Infect Dis [Internet]. 2005 [cited 202 Oct 15];37(5):350-3. Available from: https:// doi.org/10.1080/00365540510032105

93. Benova L, Mohamoud YA, Calvert C, Abu-Raddad LJ. Vertical transmission of hepatitis $\mathrm{C}$ virus: systematic review and meta-analysis. Clin Infect Dis [Internet]. 2014 Sep [cited 2020 Oct 15];59(6):765-73. Available from: https://doi.org/10.1093/cid/ciu447

94. Society for Maternal-Fetal Medicine - SMFM, Hughes BL, Page CM, Kuller JA. Hepatitis C in pregnancy: screening, treatment, and management. Am J Obstet Gynecol [Internet]. 2017 Nov [cited 2020 Oct 15];217(5):B2-12. Available from: https://doi.org/10.1016/j. ajog.2017.07.039

95. Pappalardo BL. Influence of maternal human immunodeficiency virus (HIV) coinfection on vertical transmission of hepatitis $\mathrm{C}$ virus (HCV): a meta-analysis. Int J Epidemiol [Internet]. 2003 Oct [cited 202 Oct 15];32(5):727-34. Available from: https://doi.org/10.1093/ije/dyg107

96. Hadzic N. Hepatitis C in pregnancy. Arch Dis Child Fetal Neonatal Ed [Internet]. 2001 May [cited 2020 Oct 15];84(3):F201-4. Available from: https://dx.doi.org/10.1136\%2Ffn.84.3.F201

97. Page CM, Hughes BL, Rhee EHJ, Kuller JA. Hepatitis C in pregnancy: review of current knowledge and updated recommendations for management. Obstet Gynecol Surv [Internet]. 2017 [cited 2020 Oct 15];72(6):347-55. Available from: https://doi.org/10.1097/ OGX.0000000000000442

98. Rossi RM, Wolfe C, Brokamp R, McAllister JM, Wexelblatt S, Warshak $\mathrm{CR}$, Hall ES. Reported prevalence of maternal hepatitis $\mathrm{C}$ virus 
infection in the United States. Obstet Gynecol [Internet]. 2020 Feb [cited 2020 Oct 15];135(2):387-95. Available from: https://doi.org/10.1097/ AOG.0000000000003644

99. Kushner T, Terrault NA. Hepatitis C in pregnancy: a unique opportunity to improve the hepatitis $\mathrm{C}$ cascade of care. Hepatol Commun [Internet].
2018 Nov [cited 2020 Oct 15];3(1):20-8. Available from: https://doi. org/10.1002/hep4.1282

100.European Paediatric Hepatitis C Virus Network. Effects of mode of delivery and infant feeding on the risk of mother-to-child transmission of hepatitis C virus. BJOG [Internet]. 2001 Apr [cited 2020 Oct 15];108(4):3717. Available from: https://doi.org/10.1111/j.1471-0528.2001.00088.x 